\title{
Parkinson's Disease Quick Reference Guide
}

\section{Diagnosis and Prognosis}

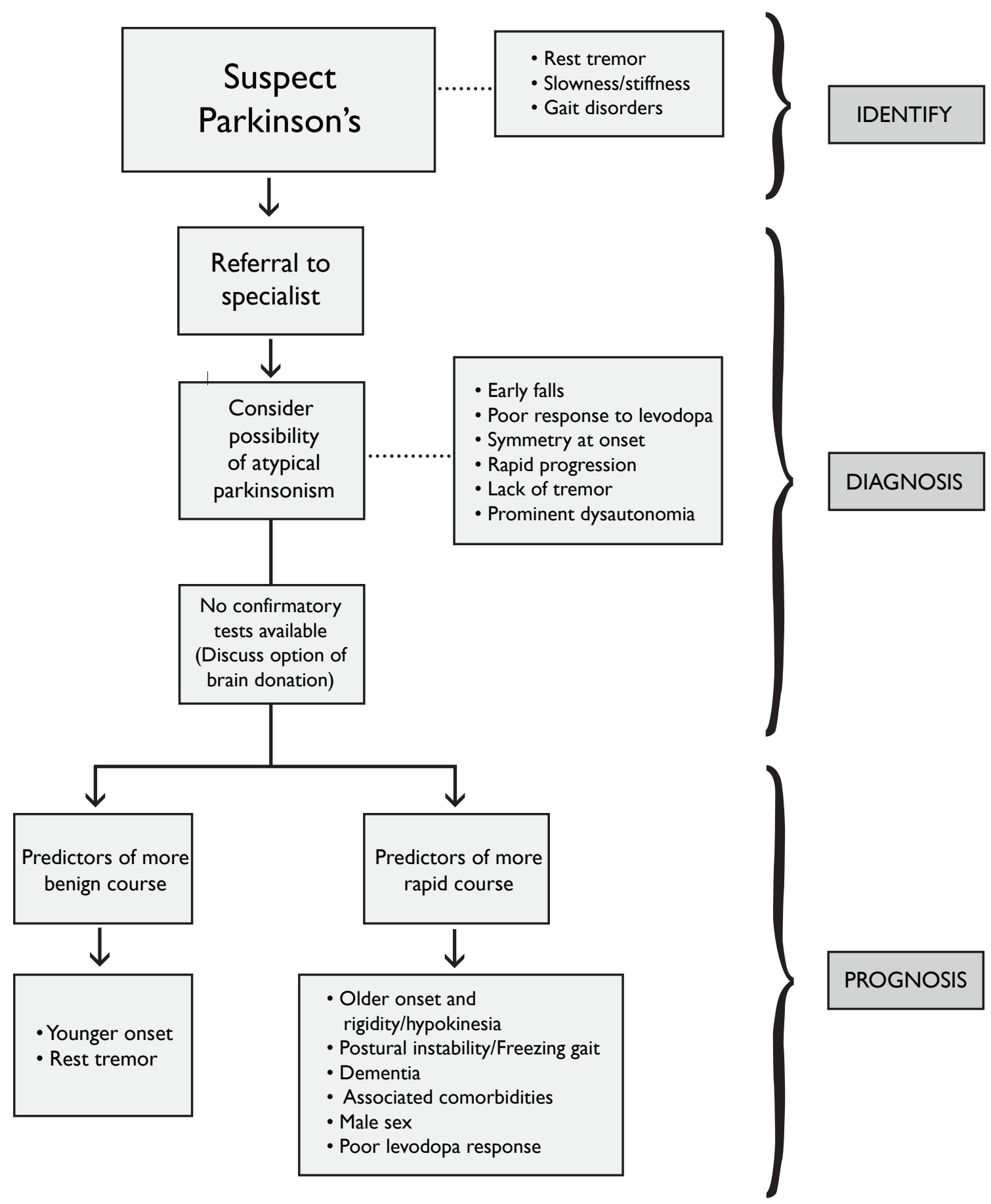

These guidelines are endorsed by

the Canadian Neurological Sciences Federation

This Quick Reference Guide made possible through unrestricted educational grants from Abbott Laboratories, Merck Canada Inc., Novartis Pharmaceuticals Canada Inc., Teva Canada Innovation and UCB Canada Inc. 
Pharmacological Therapy for Motor Symptoms in Early PD

The choice of drug first prescribed should take into account clinical and lifestyle characteristics and patient preference, after the patient has been informed of the short- and long-term benefits and drawbacks of the drug classes.

\begin{tabular}{|c|c|}
\hline \multicolumn{2}{|c|}{$\begin{array}{l}\text { Medications Effective for Early Symptomatic } \\
\text { Treatment (currently available in Canada)* }\end{array}$} \\
\hline $\begin{array}{l}\text { - MAO-B inhibitors (A) } \\
\text { - rasagiline } \\
\text { - selegiline }\end{array}$ & $\begin{array}{l}\text { - Dopamine agonists } \\
\text { - pramipexole }(A) \\
\text { - ropinirole }(A) \\
\text { - bromocriptine** }\end{array}$ \\
\hline \multirow[t]{2}{*}{$\begin{array}{l}\text { - Levodopa }(\mathrm{A}) \\
\text { - levodopa/carbidopa - } \\
\text { immediate release } \\
\text { - levodopa/benserazide - } \\
\text { immediate release }\end{array}$} & - Amantadine (D) \\
\hline & $\begin{array}{l}\text {-Anticholinergics (B) } \\
\text { - benztropine } \\
\text { - ethopropazine } \\
\text { - procyclidine } \\
\text { - trihexyphenidyl }\end{array}$ \\
\hline
\end{tabular}

\section{Pharmacological Therapy for Motor} Symptoms in Later PD

Levodopa is the most effective treatment for PD.

In the early stages of disease, the clinical response to levodopa is prolonged; however, within a few years the duration of benefit from each dose may become progressively shorter.

\begin{tabular}{|l|l|}
\hline \multicolumn{2}{|c|}{$\begin{array}{c}\text { Treatment Options for Motor } \\
\text { Complications* }\end{array}$} \\
\hline Reduce Off Time & Other Options \\
\hline First Line & $\begin{array}{l}\text { Levodopa modified } \\
\text { release (B) }\end{array}$ \\
\hline Entacapone (A) & DBS STN (C) \\
\hline Rasagiline (A) & DBS GPi (D) \\
\hline Pramipexole (B) & \\
\hline Ropinirole (B) & \\
\hline Reduce Dyskinesia & \\
\hline Amantadine (C) & \\
\hline $\begin{array}{l}\text { Deep brain stimulation (DBS) } \\
\text { subthalamic nucleus } \\
\text { (STN) (C) }\end{array}$ & \\
\hline $\begin{array}{l}\text { DBS globus pallidus } \\
\text { internus (GPi) (D) }\end{array}$ & \\
\hline
\end{tabular}

\begin{tabular}{|c|c|}
\hline \multicolumn{2}{|r|}{ Non-Motor Symptoms of PD } \\
\hline Mental Health & \\
\hline Depression & $\begin{array}{l}\text { Reported to occur in up to } 50 \% \text { of cases of PD } \\
\text { Maintain high index of suspicion; clinical features of depression overlap with the motor } \\
\text { features of PD }\end{array}$ \\
\hline Psychotic symptoms & $\begin{array}{l}\text { Typical progression from illusions of presence, through pseudo hallucinations to } \\
\text { true hallucinations. Paranoia is a common accompaniment. } \\
\text { Not all hallucinations require treatment }\end{array}$ \\
\hline Dementia & $\begin{array}{l}\text { Frequency increases with disease duration } \\
\text { Simplification of medications will minimize potential central nervous system } \\
\text { effects that accentuate the cognitive dysfunction }\end{array}$ \\
\hline Sleep Disorders & $\begin{array}{l}\text { Include insomnia, excessive daytime somnolence, REM sleep behaviour disorder } \\
\text { and restless legs syndrome } \\
\text { Advised to be aware of their provincial legislation regarding driving in patients who } \\
\text { are experiencing sleep attacks }\end{array}$ \\
\hline Autonomic Disturbance & \\
\hline Urinary dysfunction & $\begin{array}{l}\text { Most common forms are urgency, frequency and nocturia } \\
\text { Prostatic hypertrophy must be ruled out in men }\end{array}$ \\
\hline Constipation & $\begin{array}{l}\text { Dysmotility in PD is caused by lower GI dysfunction and a slowing of transit time } \\
\text { through the entire Gl tract } \\
\text { Good quality data is lacking for most suggested therapies for constipation in PD }\end{array}$ \\
\hline Erectile dysfunction & $\begin{array}{l}\text { In addition to the dysautonomia caused by the PD, mood dysfunction, motor } \\
\text { disability and side effects of medications may also contribute significantly. Add sildenafil }\end{array}$ \\
\hline Orthostatic hypotension & $\begin{array}{l}\text { Causes include: poor intake of fluids; side-effects of general medications such as } \\
\text { antihypertensives, antidepressants, diuretics; other medical conditions such as } \\
\text { cardiac dysfunction, diabetic neuropathy, PD dysautonomia; and side-effects of all } \\
\text { PD medications especially dopamine agonists. }\end{array}$ \\
\hline
\end{tabular}

